\title{
Lo caballeresco en la iconografía cristiana medieval
}

$\mathrm{E}$ l CABAllero y la CABallería, como expresión plástico-artística, quedaron integrados dentro de los grandes ciclos iconográficos de la Edad Media. Así, los ángeles y los amantes son caballeros, los soldados lo son exclusivamente y los reyes también quieren ser y son caballeros. En definitiva, ¿por qué la figuración de la personalidad masculina medieval: santo, rey, noble... acaba por representarse en la mayoría de las ocasiones con la imagen excelsa del perfecto caballero, del caballero cristiano? La representación "a lo caballeresco" de los diversos y consagrados ciclos iconográficos medievales nos habla de todo ello y es el reflejo más genuino y directo de la influencia de que gozó la ideología caballeresca en su tiempo.

A su vez, manifiesta el empuje de una particular cultura laica y la estima que socialmente alcanzó en el medievo su prototipo humano: el caballero. También, cómo se expandió y caló en todos los niveles de las estructuras sociopolíticas que dominaban la vida europea entre los siglos XIII y Xv, estructuras que necesitaban una nueva imagen para reflejar la transición política que supuso el traspaso de poderes del sistema feudal, de ámbito rural, hacia el embrionario concepto de Estado moderno representado y centralizado en la figura del príncipe, de espacio urbano. Esta nueva situación pudo consumarse porque se utilizó como elemento catalizador el tradicional sistema de vasallaje que seguía basando su éxito político en las antiguas relaciones personales de clientela y que fue reconocido como punto de encuentro válido 
por ambas partes. Por tanto, se apelaba al credo caballeresco basado en el concepto de lealtad y, sobre todo, de honor como virtudes personales que garantizaran la fidelidad al nuevo sistema de gobierno en ciernes y a la figura del caballero y la institución caballeresca como lenguaje articulador de esta nueva realidad política.

Como representante de esta nueva situación, la estética caballeresca se expandió como género además de integrarse en otros ya existentes, porque si la imagen de lo caballeresco se hubiera presentado como algo exclusivo o unilateral, habría perdido la autoridad que todo icono necesita para autentificarse en la mentalidad de su tiempo como un eslabón más de la memoria histórica. La estética caballeresca, como proyecto iconográfico, se introdujo de forma paulatina y persistente en la retina del europeo medieval con un valor máximo. En ocasiones, la exclusividad de este tratamiento "caballeresco" provocó una fuerte uniformidad visual y una dificultad ańadida a la hora de relacionar escenas y personajes correspondientes a ciclos o géneros diversos. Esta homogeneidad iconográfica produce dificultades en el espectador para una correcta identificación y contextualización temática, pero, a cambio, se unifica el mensaje ideológico: el caballero como compendio de virtudes personales y la caballería como ideología reveladora de la perfección moral y espiritual en continua lucha contra el Mal. Muchas de estas imágenes pervivirán con autoridad hasta el día de hoy en nuestra memoria colectiva.

Nos centraremos en la adopción de la estética caballeresca por parte de la Iglesia para su propia iconografía y viceversa. Para llegar hasta aquí, debemos conocer el arduo camino de depuración y adaptación ideológica que ambas doctrinas, la caballeresca y la cristiana, debieron salvar hasta presentarse como una imagen compacta y sin conflictos doctrinales, en un proceso que se remonta al propio origen de la caballería "cristiana" y conforma, por tanto, su intrínseca idiosincrasia, que la distingue de las "otras caballerías".

El origen religioso o seglar de la caballería medieval y su inherente relación con la Iglesia católica nos presentan conceptos aparentemente contradictorios. Esta discordancia desaparece cuando se puntualiza la terminología y se fijan los espacios temporales. El desajuste se produce porque se asimila erróneamente el concepto genérico de lo religioso con el más específico de lo cristiano. 
La mayoría de los estudiosos que defienden el origen "religioso" de la caballería medieval apelan a un concepto antropológico-mágico. A este sentido del término recurre Johan Huizinga, ${ }^{\mathrm{I}}$ cuando señala el origen "religioso" de la mayoría de las prácticas caballerescas, como reminiscencia de los ritos de pubertad y de la sociedad de varones de la cultura germánica. Cuando Maurice Keen ${ }^{2}$ sostiene que el origen de la caballería es puramente "seglar", destaca la caballería como un producto genuinamente feudal, es decir, territorial, donde los nuevos cambios sociales, militares y cortesanos se enmarcan dentro de un sistema jurídico propio que configura este nuevo tipo de caballería. Bernabé Martínez Ruiz ${ }^{3}$ puntualiza aún más: que el nacimiento de la caballería medieval es el resultado natural del desarrollo de la caballería merovingia a través del contacto producido en sus enfrentamientos con los pueblos bárbaros. Como puede intuirse, no hay tal contradicción entre lo "religioso" y lo "profano". Si la caballería se constituye en uno de los poderes fácticos medievales es, precisamente, por ese carácter atávico y sagrado de todo cuanto implica la práctica guerrera para la civilización humana, la cual también opera como fuerte medio de aculturación entre los pueblos contendientes. En todo ello estriba su fuerza frente a la impresionante potencia plástica de la liturgia cristiana. La Iglesia encontró uno de sus mayores escollos en esa expresión cultural de la espiritualidad bélica de las primitivas culturas europeas, especialmente la germana, que colmaba de contenido el impacto visual de los rituales caballerescos medievales. Se optó por conciliar los rituales ancestrales de guerra dentro de una nueva liturgia cristiana. Por tanto, la influencia de lo "cristiano" no se encuentra en la génesis de la caballería medieval. Su impronta se verifica más tarde como agente evolutivo y con las Cruzadas como fondo. Es entonces cuando la imagen del caballero como soldado de Cristo ${ }^{4}$ revalorizará la naturaleza de la actividad bélica, sumando al caballero una cualidad de rango espiritual de la que antes no gozaba el simple guerrero. ${ }^{5}$

La influencia y particular relación que la Iglesia mantuvo con la institución caballeresca, tanto en lo militar como en lo político, constituyó un duro y lar-

I. Johan Huizinga, El otoño de la Edad Media, Madrid, Alianza, I978, p. I 13.

2. Maurice Keen, La caballería, Barcelona, Ariel, I986, pp. 34-66.

3. Bernabé Martínez Ruiz, "La investidura de armas en Castilla", Cuadernos de Historia de España, Universidad de Buenos Aires-Facultad de Filosofía y Letras-Instituto de Historia de España, 1944, vols. I y 2, p. I95.

4. Leon Gautier, Chivalry, Nueva York, Crescent Books, I989, p. 2.

5. Josef Fleckenstein, La caballería y el mundo caballeresco, Madrid, Siglo XxI, 2006, p. 9. 
go proceso de depuración y maduración interna hasta poder presentarla e integrarla sin conflictos morales ni teologales ante su propia doctrina. Esta doctrina novotestamentaria de carácter pacifista estaba fuertemente consolidada, ya que se encontraba vigente desde los tiempos de la Iglesia primitiva e incluso perduró más allá de la caída del Imperio romano. La evidente imposibilidad de erradicar la guerra y, sobre todo, la conversión de Constantino (3I3 d.C.) obligaron a la Iglesia a justificar sus acciones bélicas, lo cual provocó un conflicto interno entre la corriente pacifista y la nueva de carácter militante, que fue legitimada teológicamente por san Agustín (354-430). Éste basó su alegato en la tradición militante del Antiguo Testamento y en la influencia moral e intelectual que sobre él ejercieron san Ambrosio (340-397) —obispo de Milán y uno de los primeros padres de la Iglesia, quien justificó plenamente la guerra y comenzó su proceso de cristianización- y Cicerón. San Agustín desarrolló el concepto de bellum iustum en su obra De civitate Dei, en la que autorizaba la guerra como recurso legal y moral in extremis, necesario para restaurar la justicia, y al mismo tiempo asumía la imposibilidad de la paz completa como una realidad inalcanzable. $^{6}$

por consiguiente no violan este precepto, no matarás, los que por mandado de Dios declararon guerras, ó representando la potestad pública, y obrando según el imperio de la justicia, castigaron á los facinerosos y perversos, quitándoles la vida. ${ }^{7}$

Esta paz pretenden las molestas y ruinosas guerras, esta alcanza la que estima por gloriosa victoria, y quando vencen los que tenían causa justa, ¿quién duda que fué digna de parabién la victoria, y que sucedió la paz que se pudo desear?

El continuo asedio de fuerzas paganas acabó por decantar a la Iglesia hacia este cambio ideológico, máxime cuando se atacaba y saqueaba a Roma (4Io d.C.), emblema de la cristiandad, y era obvia la necesidad de una defensa puramente militar, por lo que Teodosio II (4OI-450) cristianizó al ejército mediante un edicto que excluía de él a todos los soldados paganos. ${ }^{9}$

Durante los siglos x y XI, los violentos enfrentamientos entre señores feudales resultaron endémicos en la vida de Europa y generaron un fuerte vacío de

6. San Agustín, De civitate Dei, Madrid, Santillana, I795, vol. Io, lib. XIX, cap. XXviI, pp. 458-464.

7. San Agustín, op. cit., vol. I, lib. I, cap. xxI, p. 96.

8. Ibidem, vol. viII, lib. Xv, cap. IV, p. I54.

9. Philippe Contamine, La guerra en la Edad Media, Barcelona, Labor, 1984, pp. 33 I-332. 
poder. Ya en el mismo siglo XI, los sucesivos papas recurrieron al concepto de guerra santa. León IX (I049-I057) lo empleó para emprender sus campañas en defensa de los territorios de la Iglesia y Alejandro II (I06I-I073) lo aplicó a la Reconquista española. Las invasiones paganas del siglo XI fueron aprovechadas por la máxima autoridad eclesiástica para justificar y argumentar el posterior llamamiento a las Cruzadas. El papa Gregorio VII (I073-I085) articuló la situación establecida al tomar como modelo a caballeros como Erlembaldo Cotta, jefe militar de la pataria milanesa, ${ }^{10}$ y elaborar un nuevo concepto: el de la miles sancti Petri. ${ }^{I I}$ En línea con esta reforma moral de la clase guerrera, hacia I090, el obispo Bonizón de Sutri (I045-I090) estableció el código del caballero cristiano en su Liber de vita cristiana, donde exhorta al caballero a someterse a su señor, a renunciar al botín, a luchar por el bien de la res publi$c a$, a pelear contra los herejes y a proteger a los pobres, las viudas y los huérfanos. En esta defensa de los débiles y de la fe cristiana se encuentra implícita la necesidad de proteger no sólo a los fieles más desamparados, sino a la propia Iglesia y sus bienes materiales. Para ello presentó la figura del monarca como representante del poder terrenal y, por tanto, lo constrińó a asumir la responsabilidad de defender militarmente sus propios intereses terrenales. ${ }^{\mathrm{I2}} \mathrm{El}$ papa Urbano II (I088-1099), en noviembre de I095, durante el Concilio de Clermont, apeló a todo ello y ańadió el concepto de peregrinación a Tierra Santa, cuando, a la voz de la famosa exhortación final de "Dios lo quiere", proclamó la primera Cruzada contra los turcos selyúcidas en respuesta a la petición de auxilio del emperador Alejo I Comneno (I048-i I i8). Esta declaración no sólo contenía y justificaba el concepto de bellum sacrum o guerra santa y, por tanto, la posibilidad de salvar al nuevo caballero de Cristo mediante la concesión de indulgencias a los supervivientes (lo que posteriormente originó la Reforma luterana), pues fue más allá en la promesa de santidad para los caídos. También se recogía en todo ello el conflicto político de las investiduras y la precedencia de la autoridad espiritual o secular protagonizado por su antecesor Gregorio VII y el emperador Enrique IV (I050-I IO6). Durante estos dos

Io. Movimiento de reforma que surge en la segunda mitad del siglo XI en la diócesis de Milán para eliminar al clero corrupto. Los principales promotores fueron los clérigos Arialdo y Anselmo de Baggio (futuro Alejandro II) y Landolfo Cotta junto con su hermano el caballero Erlembaldo. La mayoría de ellos murieron violentamente.

I I. Franco Cardini, "El guerrero y el caballero", en Jacques Le Goff (ed.), El hombre medieval, Madrid, Alianza, I990, p. 89.

I2. Fleckenstein, op. cit., pp. 87-90. 
siglos y a través de diversos concilios se perfiló una serie de reglas que intentaban disminuir la elevada cota de violencia que debilitaba a Europa. Pero no fue hasta comienzos del siglo XII cuando la propia Iglesia entendió la imperiosa necesidad de aplicar una fortísima reglamentación sobre la guerra feudal o, en definitiva, sobre la violencia cotidiana, denominada pax Dei, vital para entender la relación entre la moral cristiana, la nueva ética caballeresca y el concepto de Cruzada. ${ }^{13}$ La "paz de Dios" protegía a los no profesionales (eclesiásticos, mujeres y nińos, campesinos, peregrinos, etc.) y los bienes públicos (molinos, iglesias, cosechas y animales de tiro), y, significativamente, sustituyó a la llamada "paz del rey". ${ }^{14}$ Asimismo, los periodos de guerra quedaban marcados por la tregua Dei, "tregua de Dios", que prohibía la lucha en Adviento, Cuaresma y Pascua, y desde el viernes por la tarde hasta el lunes por la mañana. Tampoco se luchaba en invierno, de noche o cuando llovía. El quebrantamiento de esta norma era perseguido enérgicamente por el "Tribunal de la Paz", tanto con severas penas físicas (amputaciones de miembros), como espirituales (excomuniones, maldiciones y expulsiones de la Iglesia). ${ }^{\text {is }}$ A mediados del siglo XII, Juan de Salisbury, secretario del arzobispo de Canterbury, Tomás Becket, refleja la tensión entre el poder espiritual y el terrenal en su Policraticus. Cuando la Iglesia confiere moralmente al príncipe el poder temporal y la función práctica de gobernar y defender que secularmente ya tenía, recordándole la obligación de regular y administrar la enconada violencia existente, éste delega la función militar directamente en la institución caballeresca como guardiana de la paz y articuladora de la reglamentación de la guerra. En todo ello la caballería encuentra el medio de integrar su actividad y definir su credo, lo que da vía libre a su participación en las Cruzadas como guerra justa destinada a recuperar los Santos Lugares y como guerra santa consagrada a la lucha contra el infiel. ${ }^{16}$

En Castilla, Alfonso X aborda el asunto con gran independencia del poder papal a pesar de la misma situación de guerra santa que se podía reconocer en la conflagración peninsular. Retomando la terminología agustina de bellum iustum y adoptando una perspectiva exclusivamente laica y, sobre todo, legal,

I3. Contamine, op. cit., pp. 340-344.

I4. Francisco J. Flores Arroyuelo, El caballero: hombre y prototipo, Universidad de Murcia, I982, p. 95 .

15. Fleckenstein, op. cit., pp. 94-97.

I6. Contamine, op. cit., pp. 344-349, y Carlos Alvar, Introducción al Erec y Enid de Chrétien de Troyes, Madrid, Nacional, I982, pp. I4-I5. 
entiende la guerra como un recurso legítimo para recuperar o defender los intereses amenazados, colectivos o familiares:

E son cuatro maneras de guerra. La primera, llaman en latín iusta, que quiere tanto decir en romance, como derechurera, e ésta es cuando hombre la hace por cobrar lo suyo de los enemigos, o por amparar a sí mismo, e a sus cosas de ellos. La segunda manera, llaman en latín inusta, que quiere tanto decir, como en guerra que se mueve por soberbia. La tercera, llaman civilis, que quiere tanto decir como guerra que se levanta entre los moradores de algún lugar, en manera de bandos, o en el reino por desacuerdo que ha la gente entre sí. La cuarta, llaman plusquam civilis, que quiere decir tanto como guerra en que combaten no tan solamente los ciudadanos de algún lugar, más aún los parientes de un lugar a otro, unos con otros, por razón de bando, así como fue entre César y Pompeyo. ${ }^{17}$

Identificamos aquí varios matices: la ayuda militar brindada al Imperio de Oriente, y también al de Occidente, para reconquistar los Santos Lugares y peregrinar a Jerusalén... En definitiva, un acto penitencial y una operación militar de finalidad escatológica ${ }^{18}$ que presentaban a la caballería como el brazo armado de la Iglesia militante bajo órdenes directas del Papa. El uso de terminología religiosa como "orden" y "regla" reflejaba definitivamente el triunfo de la corriente militante que generaba así su propio estado religioso-caballeresco, alcanzado por medio de una ordenación o sacramento ${ }^{\mathrm{I} 9}$ y no vía una investidura de armas. Ejemplo de todo ello es la obra de Godofredo de Charny, Livre de chevalerie, que presenta la caballería como medio de redención. La salvación de las almas guerreras se puede conseguir gracias al servicio de la orden caballeresca hacia Dios y aun se podía llegar más allá: los caballeros caídos alcanzarían la palma del martirio.

Pero esto no nos debe llevar a engaño. La organización práctica se constituyó al más puro estilo militar y, a pesar de que las Cruzadas representaban un ideal que conjuraba los deseos eclesiástico-militares, no llegaron a satisfacerlos todos al mismo tiempo. La invitación de la Iglesia a transformar la vida caballeresca, profundamente confrontada y criticada por su eminente doctor Bernardo de Claraval (I090-II53), era inviable y la vida monástica de los caba-

I7. Alfonso X de Castilla, Las siete partidas, Sánchez-Arcilla (ed.), Madrid, Reus, 2004, lib. II, XXIII, I, p. 302.

I8. Jean Flori, Caballeros y caballería en la Edad Media, Barcelona, Paidós, 200I, p. I92.

19. Georges Duby, Los tres órdenes o lo imaginario del feudalismo, Barcelona, Crítica, I985, p. 384 . 
lleros de órdenes militares religiosas parece que "moderada". La idea de Cruzada, como aventura caballeresca e indulgencia a un tiempo, provocó que la segunda generación de cruzados entendiera el proceso más como una peregrinación obligada por su estatus aristocrático que por la defensa permanente de los Santos Lugares. Por otro lado, se pedía al caballero que abandonara actividades cortesanas, lujo, amor y poesía por una regla extremadamente estricta basada en el ideal monástico. La jerarquía eclesiástica puso en práctica medidas coercitivas. La entrada en las órdenes militares religiosas impedía la pertenencia a cualquier otra orden y jamás se cansó de denunciar que los verdaderos motivos de los caballeros que iban a Tierra Santa no eran piadosos, sino pura vanidad. Estas voces fueron capitaneadas tanto por Pedro el Ermitaño, de forma pragmática, como por san Bernardo, de manera teórica. El primero reclutaba a todo tipo de cristianos deseosos de luchar contra los infieles, pero fracasó ante la imposibilidad de manejar a ingentes hordas de soldados hambrientos de comida y botín, que atravesaban Europa camino a Constantinopla y, especialmente, ensañados con los judíos, a los que arrebataron 500 almas. El segundo, último padre de la Iglesia e impulsor del movimiento cisterciense, en su Liber ad milites templi de laude novae militiae, ensalzaba al templario como modelo del caballero-monje, al tiempo que condenaba al caballero seglar, al que en ningún momento se interesa por "rehabilitar" ${ }^{20}$ Pese a todo, lo único que se consiguió fue enmascarar el triunfo de los valores caballerescos y, en realidad, tras esta condena de la caballería se escondía la renuencia a aceptarla como un hecho ineludible en la sociedad de la época, aunque tuviera un matiz monacal y, paradójicamente, aunque resultara ineficaz. La pérdida de Jerusalén, un siglo después de su conquista, se debió a que los valores caballerescos primaron sobre los estrictamente militares y la necesaria estrategia militar fue remplazada por elegantes formas de lucha ${ }^{21}$ que resultaron inoperantes porque el enemigo no aceptó las reglas del "juego". La Iglesia no supo valorar la profundidad de las ancestrales raíces caballerescas y a pesar de que su propósito real al convocar a la guerra santa era legitimar el "derecho" de la Iglesia a ostentar el mando militar con plenos poderes, esto no llegó a producirse nunca. Urbano II no tomó el poder del ejército cristiano en la Primera Cruzada (I097-I099) y se nombró a un legado papal en la persona del obispo Ademado de Puy. Y es que la caballería, desde el primer momento, ya había luchado contra los paganos

20. Cardini, op. cit., pp. 98-99.

2I. Huizinga, op. cit., p. I29. 
en el periodo carolingio sin que hubiera ninguna disociación en su estatus de guerrero cristiano. El vasallaje a su señor no afectaba el servicio de Dios. Se servía a dos señores de naturaleza distinta, el terrenal y el celestial, a un tiempo. Ellos eran soldados cristianos desde la cuna y por su bautismo, sin necesidad de consagración o pertenencia a grupo religioso-militar alguno. Así pues, prolongados los deseos de cruzada en las latitudes meridionales de la península ibérica, la Iglesia, ya experimentada en Oriente, dejaba la iniciativa militar en manos de los monarcas castellanos y simplemente ofrecía su "apoyo" espiritual y económico a través de indulgencias a los caballeros y ayudas económicas a los monarcas. Como afirma Diego de Valera, para tal fin

el rey acordó de llamar solamente tres mill hombres de armas, repartidos entre los grandes de sus reynos, contando entre éstos los continos de su casa e algunos vasallos suyos, no de grande estado; y con éstos y con la gente del Andalucía e con veinte mill peones, le parecía asaz para hacer la guerra como convenía. Y determinose que el rey embiase al Sancto Padre Calisto tercero le quisiese ayudar con el tesoro de la Iglesia, dándole plenaria yndulgencia so cierta forma para biuos e muertos, la qual yndulgencia le fue dada por Nicolao quinto, sucesor ynmediato que fué de Calisto tercero. ${ }^{22}$

La verdadera relación entre caballería e Iglesia se realizaba cotidianamente dentro de las grandes familias a través de sus propios monasterios de fundación. Este contacto fue mucho más cercano y continuado que la lejana autoridad papal. Se resolvía ampliamente dentro de las necesidades de formación de los jóvenes aristócratas, futuros caballeros de linaje, ya que los monjes cuidaban a la par la preparación espiritual y la seglar. Allí tenían contacto con los cantares de gesta y con los tratados de caballería, con los héroes clásicos o con los blasones de su linaje que continuamente les hablaban de heroicidades familiares que insuflaban en sus ánimos la obligación de participar en aventuras futuras. A su monasterio donarían parte de su botín o de sus trofeos y allí recibirían cristiana sepultura. Esta privilegiada relación, el binomio nobleza-monacato, proviene de los tiempos carolingios y también contribuyó a la expansión del monaquis-

22. Diego de Valera, Memorial de diversas hazañas, Juan de Mata Carriazo (ed.), Madrid, Espasa Calpe, I94I, cap. III, p. 9. 
mo en Occidente, reflejado en una especie de estado religioso específicamente caballeresco que define el concepto de caballero cristiano $^{23}$ en íntima relación con la conocida como "piedad caballeresca". Aunque sobre este concepto hay discrepancias, Huizinga ${ }^{24}$ no considera al monacato suficiente influencia y señala, de nuevo, las prácticas germanas precristianas como antecedente muy anterior y más arraigado en la idiosincrasia caballeresca. En los mismos términos se expresa Cardini ${ }^{25}$ cuando refiere que en este concepto - que abarca el servicio al Altísimo como a un seńor feudal, el culto a la Virgen María como la dama celestial, la búsqueda de la patria divina a través de la peregrinación a Jerusalén, la disposición al martirio junto con la fidelidad a los compañeros de armas, la lealtad y la admiración hacia los guerreros enemigos- no influye la experiencia de las cruzadas. Muy distinta es la opinión de José Enrique Ruiz Doménech, ${ }^{26}$ quien afirma categóricamente que la caballería y su credo personal fueron una creación exclusiva de la reforma cisterciense del siglo XII. Los ideólogos eclesiales atribuyeron a las virtudes caballerescas todo un contenido místico que dejaba el plano religioso por encima del guerrero-vasallático. La finalidad era acabar con el propio sistema feudal e implantar el imperial, que nacía ya bajo el sometimiento moral a la Iglesia, como lo demuestra el apelativo "sacro imperio". La caballería se constituiría, por tanto, en uno de los pilares donde se asentaría el nuevo concepto de soberanía, convirtiendo al señor feudal en un noble palatino, un caballero cuyos nuevos valores debían exponerse pública y estéticamente para dar a conocer su nueva condición.

A pesar de la imagen tan codificada que ofrecían los ciclos iconográficos cristianos, debido al proceso evangelizador del románico, se tendía, como bien señala Joaquín Yarza, ${ }^{27}$ a integrar la iconografía profana en la cosmología cristiana, proceso que culminará en los siglos XIV y Xv. Podemos apreciar una especial simbología caballeresca en la iconografía cristiana medieval instalada, sobre todo, en los ciclos cristológico y hagiográfico. Seguidamente veremos cómo Cristo representará el símbolo caballeresco por excelencia, la máxima jerarquía a la cabeza de un ejército celestial comandado por san Miguel y formado en sus

23. Giovanni Miccoli, "Los monjes", en Le Goff (ed.), op. cit., pp. 57-63.

24. Huizinga, op. cit., p. II3.

25. Cardini, op. cit., p. I03.

26. José Enrique Ruiz Doménech, El laberinto cortesano de la caballería, Barcelona, Universidad Autónoma de Barcelona, I98I-I982, pp. I6-I7.

27. Joaquín Yarza Luaces, Los Reyes Católicos. Paisaje artístico de una monarquía, Madrid, Nerea, 1993, p. I80. 
huestes por santos caballeros cuyo patrón es san Jorge. Su símbolo de martirio, la cruz, aparecerá como el estandarte triunfal de esta contienda "militar" contra el pecado. La Virgen María cierra este ciclo épico-religioso como la gran dama cuya sola virtud vence al pecado y a la que se rinde pleitesía caballeresca, mientras ella, contemplativamente, intercede por sus protegidos. En el ámbito militar, el culto a la Virgen procede de Bizancio, donde el icono mariano tenía fuertes poderes taumatúrgicos. Ella y su hijo son la génesis del preciado botín que constituye el duelo entre Dios Padre y el demonio, representado como un dragón en el primer momento de batalla celestial.

Una gran señal apareció en el cielo: una Mujer revestida del sol, con la luna bajo sus pies y una corona de doce estrellas sobre la cabeza. Estaba encinta, y gritaba con los dolores de parto y las angustias de dar a luz. Otra señal apareció en el cielo: un dragón color de fuego, con siete cabezas y diez cuernos; sobre sus cabezas, siete diademas; su cola arrastraba la tercera parte de las estrellas del cielo y las lanzó sobre la tierra. El dragón se puso delante de la Mujer en trance de dar a luz, para devorar al hijo tan pronto como le diera a luz. Ella dio a luz un hijo varón, el que debía apacentar a todas las naciones con una vara de hierro. El hijo fue arrebatado hacia Dios y a su trono. Y la Mujer huyó al desierto, donde tiene un lugar preparado por Dios, para ser alimentada allí durante mil doscientos sesenta días. Entonces hubo una batalla en el cielo: Miguel y sus ángeles lucharon contra el dragón. ${ }^{28}$

Todo este proceso, que la Iglesia debe recorrer para conciliar su doctrina con la realidad político-militar en que vive, tiene su consecuencia directa e inmediata en la iconografía cristiana medieval. Iconográficamente, la Iglesia, desde los primeros días, debió convivir en un difícil equilibrio entre su doctrina de origen hebreo y su propio sistema iconográfico de procedencia pagana. El sincretismo producido entre el contenido y el continente de su imagen pública, la aculturación entre dominado y dominador, se constituyó rápidamente en un arma de doble filo. Por una parte, sirviéndose de un sistema iconográfico ajeno tomado del propio sistema imperial, se multiplicaban las expectativas de captación y expansión de la doctrina, al tiempo que, en un principio, las mantenía en la clandestinidad. Por otro lado, una vez superadas las necesidades primarias de supervivencia y evangelización, los doctos pusieron de relieve la débil línea que unía imagen y símbolo, y la necesidad de una mayor base 
intelectual que argumentara iconológicamente su - ya propio- sistema iconográfico. Para entonces, el sincretismo de la imagen cristiana se había constituido en pura tradición y, paradójicamente, la fuerza de ésta mantuvo en jaque a la propia doctrina en lo sucesivo. Desde los primitivos concilios que culminaron con la polémica abierta entre iconoclastas e iconódulos en el siglo viII hasta llegar a los tiempos de la Contrarreforma, la Iglesia vio cómo debía protegerse y regular periódicamente su propia producción figurativa.

A todo ello se suma el conflicto interno, ya mencionado, que generó la obligada adaptación de la primitiva corriente pacifista e integradora a toda una ideología, llámese militarista o activista, proveniente tanto de la tradición judaica como de la pagana. Fue san Pablo, ejemplo de predicador beligerante, judío fariseo de Tarso, quien recoge esta tradición y participa de esta línea activista a la hora de desarrollar su misión evangelizadora con los gentiles o paganos. San Pablo utiliza expresiones como "buen soldado de Cristo", ${ }^{29}$ proyecta la imagen de Dios como defensor de su pueblo ante el maligno ${ }^{30}$ y emplea asiduamente palabras violentas como "lucha" y "batalla". En el epílogo de la carta a los efesios, exhorta a la lucha espiritual en estos términos:

En definitiva, confortaos en el Señor y en la fuerza de su poder. Revestíos de la armadura de Dios para que podáis resistir las tentaciones del diablo. Porque nuestra lucha no es contra la carne y la sangre, sino contra los principados y potestades, contra los dominadores de este mundo tenebroso, contra los espíritus malos que andan por los aires. Por esto, recibid la armadura de Dios para que podáis resistir en el día malo y ser perfectos en todo. Estad, pues, firmes, ceñidos vuestros lomos con la verdad y revestidos con la coraza de la justicia, y teniendo calzados los pies, prontos para anunciar el Evangelio de la paz. Empuñad en todas las ocasiones el escudo de la fe, con el cual podáis inutilizar los dardos encendidos del maligno.

Tomad también el yelmo de la salud y la espada del Espíritu, que es la palabra de Dios; orando en todo tiempo en el Espíritu con toda clase de oraciones y súplicas y velando a este fin con toda perseverancia y súplica por los santos, y por mí, para que sean dadas las palabras aptas cuando abro mi boca para anunciar con valentía el misterio de Cristo, del cual soy su embajador, prisionero, de modo que me atreva a hablar libremente de él como conviene. ${ }^{3 \mathrm{I}}$

\footnotetext{
29. Timoteo, 2, 3.

30. Tesalonicenses, 3,5 .

31. Efesios, 6, го-24.
} 
¿Qué había cambiado para que el Imperio no temiese la nueva doctrina de Cristo y ésta fuera recibida por el propio emperador y su familia? En Europa, este carácter pacifista de la Iglesia primitiva disonaba tanto entre los pueblos bárbaros como en el propio Imperio. Para los germanos, cuyos jefes ostentaban simultáneamente el poder militar, civil y religioso y adoraban a una pléyade de dioses guerreros, la imagen de un pequeño hombre crucificado como ejemplo a seguir era sencillamente una entelequia, era la imagen de la derrota y el deshonor. De igual modo, para Roma, aun para su propia política de integración de los distintos panteones de los pueblos conquistados, era muy difícil aceptar a uno de ellos que, paradójicamente, había sido condenado a muerte y ejecutado por su propio sistema judicial. Se ofrecía cuanto menos una imagen de debilidad tanto jurídico-política, al admitir el error, como religiosa, con un panteón disgregado, ambiguo y sobre todo incoherente. Para Franco Cardini, ${ }^{32}$ el proceso evolutivo por el que la imagen de Cristo pasa de víctima inmolada a héroe triunfal que vence a la muerte se basa exclusivamente en una lógica guerrera adoptada para evangelizar a los pueblos germánicos. Se resalta el pecado de traición como el más grave: Lucifer traidor del Padre y Judas traidor del Hijo. Y se asimilan las metáforas de san Pablo que acabamos de leer: Cristo yelmo, Cristo escudo de guerreros... Ahora, Cristo en la cruz es un joven héroe, el dios de los ejércitos, el señor de los triunfos y los ángeles sus soldados. En definitiva, toda una prefiguración de una batalla celestial de la lucha metafísica entre el Bien y el Mal como un auténtico combate militar.

Pues previsora, la Virtud había puesto en sus hombros coraza de triple malla de acero y había añadido de todos lados escamoso tejido de hierro entre los lizos retorcidos. [...] Mas el yelmo de bronce, moldeado con metal fundido, devuelve un sonido al ser golpeado, embota por su dureza la hoja de la espada haciéndola rebotar y su metal rebelde rompe además el acero que choca contra él, al tiempo que sin saber lo que es dejar paso, recibe las vanas acometidas y resiste seguro los golpes. ${ }^{33}$

Con todo ello, se materializaba y se resaltaba el carácter viril y heroico de la contienda espiritual. Se presentaba al cristianismo como una religión que el pueblo germano podía abrazar con las mismas garantías, o mejores, de con-

32. Franco Cardini, Alle radici della cavalleria medievale, Florencia, La Nuova Italia, I98 I, pp. I64 y ss.

33. Prudencio, Psicomaquia, Madrid, Gredos, I997, pp. 374-375. 
seguir victorias sin que su doctrina les acarreara debilidad alguna. Del lado imperial, se optó por la misma solución canalizada a través del gran aparato propagandístico dirigido por Teodosio que, con visión de Estado, proyectó la imagen pública del cristianismo imperial con la leyenda de la Veracruz, encontrada por Helena, madre de Constantino, primer emperador cristiano. Con ello, se confería a la cruz el carisma de una insignia militar, un símbolo de victoria, un estandarte. De este modo, aparecerá en lo sucesivo en las numerosas iconografías que representan la entrada de la reliquia en Roma. Así la pasearán los papas en procesión hasta el Coliseo, asida y presentada como un símbolo de triunfo militar. Cristo se muestra ante el pueblo como un dios-héroe que vence en la mayor de las batallas a la muerte. Por su parte, el emperador asume su nueva función de defensor de la Iglesia como ejercicio propiciatorio de la victoria sobre los pueblos germanos. Sólo así, convirtiéndose en un símbolo militar y triunfal, real y efectivo, no exclusivamente espiritual, se aleja de la cruz el signo de la sumisión y la derrota. Todo este proceso interno se expresa en una nueva vertiente iconográfico-iconológica que se asienta sobre tres pilares principales: el teológico, el litúrgico y el hagiográfico.

Teológicamente se justificó el giro de la Iglesia hacia la corriente activista integrando los tres conceptos "evolucionados": el veterotestamentario y el constantiniano (este último, con la figura del emperador como defensor laico de la Iglesia que se prolongará en la figura de Carlomagno), a los que se añade el concepto agustino de "guerra justa". Todo ello no sirvió para justificar las luchas entre cristianos que asolaban Europa y que aún reprobaba con energía la Iglesia, la cual, en este asunto, unía el primitivo tabú de la sangre, todavía fuertemente arraigado en la mentalidad medieval, con la observación del quinto mandamiento, "no matarás", ${ }^{34}$ y, por tanto, condenaba a la marginalidad a los soldados que combatían. ${ }^{35}$

Abraham, disipador del triunfo enemigo, regresa glorioso después de recuperar la prole de su hermano, evitando así que el poder de los más depravados caudillos dominara linaje alguno de sangre fiel. A este varón, aún manchado de tan gran matanza, el sacerdote le obsequia con platos celestiales, sacerdote de Dios y al tiempo rey poderoso, cuyo misterioso origen, de fuente inenarrable, no deja ver ningún autor

34. Exodo, 20, I3.

35. Jacques Le Goff, Lo maravilloso y lo cotidiano en el Occidente medieval, Barcelona, Gedisa, I985, pp. 88-89 у 133 . 
propio, Melquisedec, cuál su estirpe, cuáles sus antepasados, no se sabe, lo sabe sólo y exclusivamente Dios. ${ }^{36}$

\section{III}

En el ámbito litúrgico, no sólo se aceptó el ritual de las armas, pues se bendijeron tropas, armamento y estandartes que marcharon a defender los Santos Lugares y a conquistar Jerusalén, sino además la Iglesia produjo sus "propias armas", cargadas de poder taumatúrgico y simbólico a un tiempo. Eran las llamadas espadas o montantes benditos. Las otorgaban los papas a los reyes o príncipes y, excepcionalmente, a grandes personajes políticos que encabezaban la lucha contra el infiel. El Papa, la noche de Navidad, antes de la primera misa en la sacristía pontificia de San Pedro, junto con todos los cardenales revestidos, bendecía la espada y el capacete o morrión. Pedía a Dios, mediante la intercesión de san Pedro y san Pablo, fortaleza (espada) y defensa (capacete), y conservaba ambos sobre el altar hasta que se celebraba la misa mayor.

La espada también participaba como elemento de la liturgia cristiana durante el rito de la investidura de armas. Se recogía así una sacralidad que tiene su origen en los primitivos pueblos esteparios (mongol e iraní) y que fue transmitida a los "bárbaros germanos" a través del Cáucaso. Los componentes del culto germano a la espada son de origen maravilloso-divino y se ligan a un dios o a un héroe, lo que no impidió un proceso paralelo de humanización al darle nombre y conferirle personalidad, como a Excalibur, la espada del rey Arturo, o Durandarte, la de Roldán. ${ }^{37}$ Por todo ello, se les atribuyeron poderes taumatúrgicos, pues algunas de ellas contenían verdaderos relicarios en sus empuñaduras, y también mágicos. En Castilla, se creía que Lobera, la espada del rey Fernando III el Santo, hacía invencible a todo aquel que la portara, y en este sentido la utilizó Fernando de Antequera contra los musulmanes en Zahara, y luego, victorioso, en solemne procesión por las calles de Sevilla hasta la catedral, la devolvió a las propias manos del rey santo. ${ }^{38}$

36. Prudencio, op. cit., p. 365 .

37. Jean Flori, La caballería, Madrid, Alianza, 200I, p. 27.

38. Rafael Cómez Ramos, Imagen y simbolo en la Edad Media andaluza, Universidad de Sevilla, I990, pp. 96-97. 
Por último, el vexilum, estandarte o bandera bendita, provenía de una tradición constantiniana, ya mencionada, que identificaba al emperador como primer defensor laico de la Iglesia. Esta imagen la hicieron suya los grandes señores, fundadores de monasterios o defensores de diócesis que tenían el derecho de portar la bandera bendita con los símbolos sagrados o la figura del santo patrón.

En realidad, todo ello seguía reflejando el conflicto de intereses políticos entre el poder laico y el religioso. El papado se apropiaba con su autoridad moral de una campaña emprendida y sufragada económicamente por los reyes y príncipes cristianos, lo cual proyectaba una imagen de relación vasallática inexistente que colocaba a la Iglesia a la cabeza de todo poder terrenal. ${ }^{39}$

El ciclo se cierra con un nuevo repertorio hagiográfico basado en la veneración a los santos caballeros, con san Miguel a la cabeza y la caballería como sucesora y heredera del ejército celestial en la tierra. ${ }^{40}$ Conformaron la primitiva hueste una serie de militares imperiales que abandonaron las armas y se convirtieron al cristianismo. La mayoría de ellos eran mártires caídos en las persecuciones que se sucedieron desde la primera, emprendida por Decio en 249-25 I, hasta la última, consumada por Diocleciano en 303-3 I I, y un grupo de heroicos soldados que habían muerto sirviendo en el ejército bizantino. Se fomentó pues el culto rendido a estos santos militares, entre los que figuraban Eustaquio (Plácido), Martín, Mercurio, Víctor, Procopio, Sebastián, Teodoro, Demetrio, Néstor, Lupa, Sergio, Baco, etc. Representaban la milicia de Dios militia Christi.

é fueran entonces vencidos sino por la merced de Jesucristo, que les envió en su acorro á san Jorge, é á san Barbaro, é á san Diomitris, éá san Dionís, é parescieron en caballos blancos con una legion de ángeles, é la legion es seis mil e seiscientos é sesenta é seis, que venian tan récios como falcones, é hirieron en los turcos tan récio como rayos, de manera que cada uno mató el suyo. ${ }^{41}$

Pero, en una sociedad dominada por el mundo de la guerra, guiar a los ejércitos era un privilegio exclusivo de los que ostentaban el poder y portar armas

39. Cardini, Alle radici della cavalleria..., op. cit., pp. 302-305.

40. Huizinga, op. cit., p. I87.

4I. Anónimo, La gran conquista de ultramar, Madrid, Rivadeneyra, I95 I (BAE, 44), lib. II, cap. CCLXV, p. $32 \mathrm{I}$. 
significaba poseer el estatus de hombre libre. Por encima incluso del estatus jurídico y guerrero, la diferencia la marcaba a la postre el propio armamento, la superioridad del armado sobre el inerme ${ }^{42}$ de ahí que el culto a los santos militares implicara mucho más: significaba poner como ejemplo de comportamiento a toda una clase política. ${ }^{43} \mathrm{El}$ caballero podía significar un sacerdote de la guerra, un mártir de Cristo predispuesto al sacrificio por la redención de sus defendidos. ${ }^{44}$ En definitiva, una nueva injerencia de la Iglesia en el poder civil. La mayoría de estos santos adquirieron también el rango de patronos de países, ciudades o gremios, continuando así una función protectora que formaba parte del credo caballeresco: la defensa de la cristiandad y de los indefensos, cuyo origen, de nuevo, se encuentra en "la tregua" y "paz de Dios" (siglos XI-XII). 45

En la iconografía medieval de san Martín de Tours (316-397), soldado romano que abandonó el ejército para no tener que derramar sangre humana y nombrado obispo de Tours, tenemos un buen representante del primer momento: la santificación por la renuncia a las armas terrenales en pos del arma celestial: la palabra de Dios. San Martín fue patrón de dicha ciudad y prototipo del "soldado de Cristo", como a él mismo le gustaba llamarse. Su biografía, Vita Martini, la escribió a principios del siglo v Sulpicio Severo (360-4I3), al cual conoció. ${ }^{46}$ San Martín de Tours fue el producto de la llegada a Occidente, en el siglo Iv, del concepto oriental de santidad, basado en la práctica de la perfección a través del ascetismo, aunque él constituyó un caso mixto entre asceta y evangelizador que marca el carácter eclesiástico de los santos occidentales. ${ }^{47}$ Simone Martini lo representa en el momento de tomar la investidura como caballero de Cristo, al recibir las espuelas y la espada.

La promesa de santidad a través de la práctica de la caballería para la nobleza está ejemplificada en la vida de san Gerardo de Aurillac. El conde Gerardo (856-909) sigue el procedimiento de rigor de un señor feudal al fundar en 890 el monasterio de Aurillac, alrededor del cual crecerá la ciudad del mismo

42. Franco Cardini, Quell'antica festa crudele. Guerra e cultura della guerra dall'età feudale alla Grande Rivoluzione, Milán, Il Saggiatore, 1988, p. I8.

43. Cardini, Alle radici della cavalleria..., op. cit., p. 24I.

44. Cardini, Quell'antica festa..., op. cit., p. 27.

45. Fleckenstein, op. cit., pp. 92-93.

46. Hugh Farmer, The Oxford Dictionary of Saints, Oxford University, 1987, pp. 287-288.

47. André Vauchez, "El santo", en Jacques Le Goff (ed.), El hombre medieval, Madrid, Alianza, I990, p. 330. 
nombre que lo hizo su patrón. San Odón (879-942), abad de Cluny y coetáneo suyo, escribe la Vita de San Gerardo de Aurillac, donde se defendía ya la posibilidad de hallar la salvación y alcanzar la santificación mediante el servicio a la Iglesia directamente con las armas. ${ }^{48}$ Se proyectaba así desde el propio movimiento cluniacense el modelo del caballero-monje que, como vimos, en el siglo XII, el movimiento reformista cisterciense, con san Bernardo a la cabeza, aún defiende como única vía redentora.

El origen de la iconografía de estos santos caballeros se encuentra en la tradicional imagen coptobizantina del santo montado a caballo y armado, importada a Europa por peregrinos y ex mercenarios licenciados del ejército bizantino. En Occidente, exceptuando los atributos personales que hacen referencia a su martirio y los identifican, se les suele representar vestidos con armadura de la época: espada y lanza. ${ }^{49} \mathrm{La}$ armadura medieval los enmarca cronológica y estilísticamente, puesto que en el Renacimiento se les volverá a ceñir la coraza clásica. Pero, como es de suponer, los elementos diferenciadores que convierten a estos santos guerreros en santos caballeros son el caballo, la espada y la lanza portada como banderola, símbolos todos eminentemente caballerescos, pues caballo y espada son propios del rango nobiliario en que se sitúan los miembros de la caballería medieval por las connotaciones sociojurídicas que contienen. Los dos son elementos ancestrales en las civilizaciones del Viejo Mundo y, por tanto, una larga tradición figurativa, mitológica y espiritual avalaba el éxito de este modelo iconográfico.

La espada es un atributo personal y cualificador al que sólo tenían acceso los hombres libres que ostentaban algún tipo de poder público o pertenecían al ámbito militar. En el medievo, la espada es el emblema de la función caballeresca como la corona lo es de la función real. ${ }^{50}$ Éste será el contenido simbólico asimilado por la iconografía religiosa para los santos caballeros. La función caballeresca se expresa y ordena claramente en dos ámbitos: el religioso primero y el civil después. Éste es el simbolismo religioso que fielmente le atribuye Ramón Llull, ${ }^{\text {SI }}$ caballero y místico. La empuñadura simboliza la cruz, es decir,

48. Georges Duby, Hombres y estructuras de la Edad Media, Madrid, Siglo XxI, I978, pp. 222223; Contamine, op. cit., p. 344; Cardini, "El guerrero y el caballero", op. cit., p. 90.

49. Juan Ferrando Roig, Iconografía de los santos, Barcelona, Omega, I99I, p. I6.

50. Duby, op. cit., p. 388.

51. Ramón Llull, Libro de la orden de caballería, en Luis Alberto Cuenca (ed.), Floresta española de varia caballería: Raimundo Lulio, Alfonso X, Don Juan Manuel, Madrid, Nacional, 1975, pp. I88-I94. 
la defensa de la fe y la doctrina cristianas. La hoja con sus dos filos, el mantenimiento de la justicia y la defensa de los débiles. Alfonso X, coherente con el concepto laico-jurídico de la guerra que representaba, atribuye a la espada las cuatro virtudes cardinales: cordura, fortaleza, mesura y justicia. La primera de ellas, que también significa prudencia, en el mango; la fortaleza, que implicaba valentía y constancia, en la manzana de la espada; la mesura o templanza, en el arriaz, y la justicia, en el hierro de la espada. Por eso, la espada también es atributo regio.

Ca bien assi como las armas que el ome viste, para defenderse, muestran cordura, que es virtud que le guarda de todos los males que le podrian venir por su culpa; bien assi muestra esso mismo el mango del espada, que ome tiene en el puño: ca en quanto assi lo tosiere, en su poder es de alçaya, o de baxalla, o de ferir con ella, o de la dexar. E assi como las armas que ome para ante si, para defenderse, muestran fortaleza, que es virtud que faze a ome estar firme a los peligros que avinieren; assi en la mançana es toda la fortaleza de la espada, ca en ella se sufre el mango, e el arrias, e el ferro. E bien como las armaduras que el ome cińe, son medianeras entre las armaduras que se viste, e las armas con que fiere; e son assi como virtud de la mesura, entre las cosas que se fazen a demas, o de menos de lo que deven; bien a essa semejança es puesto el arrias entre el mango, e el fierro della. E bien otrosi como las armas que el ome tiene endereçadas, para ferir con ellas alli do conuiene, muestran justicia, que ha en si derecho, e igualdad; esso mismo muestra el fierro de la espada, que es derecho, e agudo, e taja igualmente de ambas las partes. E por todas estas razones establecieron los Antiguos, que la traxiessen siempre consigo los nobles Defensores; e que con ella rescibissen honrra de Caualleria, e con otra arma non: porque siempre les viniesse emiente destas quatro virtudes, que deuen ayer en si. Ca sin ellas no podrian complidamente mantener el estado del defendimiento, para que son puestos. ${ }^{52}$

Ninguno de los demás significados laicos que pueda simbolizar la espada, como el honor, riñe con su función divina. Honrando la caballería se honra a Dios, puesto que el dominio sobre este mundo prefigura el dominio eterno. ${ }^{53}$ Por tanto, la espada que empuñan los santos caballeros simboliza y sintetiza tanto

52. Alfonso X, op. cit., lib. II, XXI, IV, p. 289.

53. José G. Higuera Rubio, "Honor y dialéctica en la representación caballeresca de Ramón Llull en el Breviculum de Tomás le Myésier”, en Alexander Fidora y José G. Higuera (eds.), Ramón Llull: caballero de la fe. El arte luliana y su proyección en la Edad Media, Pamplona, Eurograf, 200I, p. 83. 
el proceso evolutivo que la Iglesia ha debido recorrer para justificar el uso de la fuerza contra el infiel, como el propio proceso fundacional de la caballería medieval europea. Y, también, simboliza la fe y la nueva ley: el Evangelio, "La espada del Espíritu que es la palabra de Dios", 54 constituye el arma que, en representación de Cristo-caballero, esgrimen en su lucha contra el pecado los grandes santos de la caballería. Es el "arma” de la evangelización.

\section{IV}

El caballo en la mitología clásica es un ser originario del inframundo. Pegaso es hijo de Poseidón, dios de las profundidades marinas, el vehículo que conduce al difunto hacia su último viaje, e incluso simboliza su propio espíritu: el mensajero del más allá. Por tanto, comparte una naturaleza divina y demoniaca al mismo tiempo que en el cristianismo ya habían asumido los símbolos telúricos en general. Así, en la iconografía coptobizantina, la representación de cualquier santo es normalmente ecuestre y simboliza la victoria sobre la muerte espiritual, sobre el pecado. También en la cultura celta y germana el caballo adopta una naturaleza demoniaca como portador de la muerte y es común en el medievo representar las almas condenadas como demonios de aspecto equino, o incluso como caballos negros. En el Mediterráneo, desde la prehistoria, el caballo, aun en el mismo contexto funerario, tiene un significado positivo: el de cualificar al difunto y ensalzar la importancia de su gesta, acompañando a su amo en su última morada como parte de su ajuar militar. Hasta el siglo XV, lo escoltará hasta la tumba como un miembro más en sus exequias. Por tanto, la simbología ambivalente del caballo y la figuración de un caballero atacando a un monstruo de forma natural se asimila básicamente como la representación de la victoria sobre la muerte: la psicomaquia, hasta el punto de que el caballo puede concebirse como un atributo más de la santidad caballeresca, semejante al nimbo. 55

La psicomaquia también incorpora una tradición iconográfica laica. La encarnación del triunfo político-militar en el Imperio romano fue transmitida a través de la imagen del militar victorioso, representada por un guerrero ecuestre con un vencido entre las patas del caballo. Esta simbología del poder

54. Efesios, 6, I7.

55. Cardini, Alle radici della cavalleria..., op. cit., pp. 38-4I y 232. 
I. Anónimo, Políptico Barberini, principios del siglo vi, París, Museo del Louvre, OA 3850.

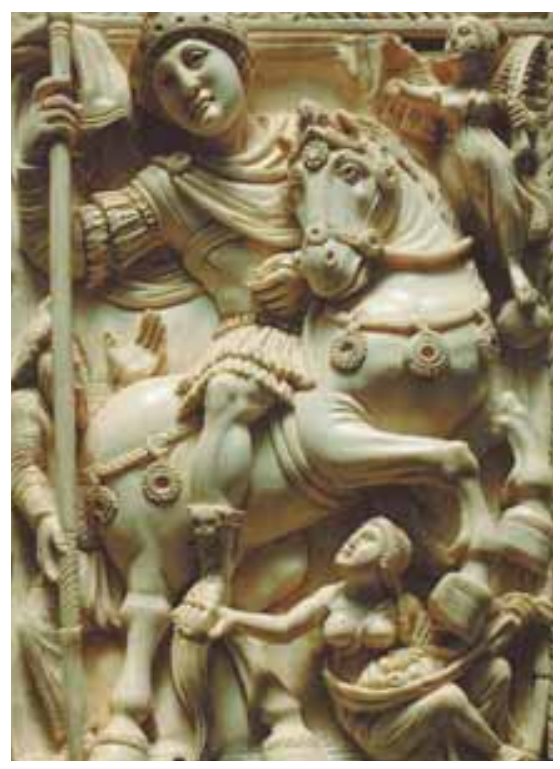

se relaciona con la variante romana del adventus imperatoris, que representa la entrada triunfal del emperador a caballo precedido por una figura femenina a pie, emblema de la victoria (fig. I). En la Edad Media, la figura ecuestre de Marco Aurelio se había tomado equivocadamente de un retrato de Constantino. Aunque hubo otros precedentes, como una moneda de Caracalla (I882I7) y otros relieves romanos, la imagen románica del caballero victorioso fue adjudicada mayormente a Carlomagno, considerado el primer caballero histórico y el legítimo sucesor imperial de Constantino. Tal iconografía laica se interpretó también "a lo divino" al relacionarse con la pax Dei y la tregua Dei, representada con un personaje situado, esta vez, entre dos jinetes enfrentados.

Como acabamos de ver, la Iglesia presenta a los santos caballeros como un nuevo culto cuidadosamente diseńado y promovido como modelo a seguir por los caballeros cristianos. Estos miembros de la militia caelesti tienen su jerarquía militar y siguen a sus propios caudillos; san Jorge encarna al santo caballero por excelencia y protagoniza, de igual manera, una psicomaquia de carácter ecuestre. La leyenda dorada ${ }^{56}$ nos lo muestra como un tribuno oriundo de Capado- 
cia que sufrió persecución en tiempos de Diocleciano y Maximiano, y que fue decapitado por Daciano después de sobrevivir milagrosamente a varios martirios. Pero el episodio más popular, en la iconografía medieval, es el que relata el rescate de la princesa de las fauces del dragón y la muerte de éste a manos del santo que, como ya hemos indicado, prefigura la victoria del Bien sobre el Mal, la vida sobre la muerte y las virtudes sobre los vicios: la ancestral lucha del alma (fig. 2).

Su culto en Occidente desde el siglo XII fue dirigido políticamente por el espíritu de las Cruzadas y, por tanto, en la época la dama se convirtió en la prefiguración de la Iglesia y san Jorge en el santo caballero por excelencia del medievo europeo y patrón de la caballería cristiana, que, como caudillo de la militia christi, acompañaba y protegía a otros caballeros en el momento sagrado de la batalla contra el infiel. ${ }^{57}$ Obviamente, todo ello se aviene a la perfección con la más tradicional iconografía épico-caballeresca y así lo vemos, al flanco de Jaime I de Mallorca en la conquista de Valencia, en el retablo encargado por el Centenar de la Plomá — compañía de ballesteros de escolta de la Real Senyera de Valencia-, que rememora la batalla del Puig (I247), donde el papel de san Jorge, según la tradición, fue determinante.

La variante de esta iconografía hagiográfica, psicomáquica y caballeresca en la cruzada occidental, es decir, en la Reconquista castellana, la representa la figura de Santiago, patrón de la caballería española. Su "predicación en la península ibérica" aparece mencionada desde mediados del siglo viı en un breviario de origen griego, el Breviarum apostolorum, si bien la noticia procedía de una interpolación en un escrito de san Isidoro: el De ortu et obitu patrum, difundido poco después de su muerte en 636. Aunque se demostró su carácter apócrifo, este breviario y su noticia jacobea tuvieron más eco en el resto de Europa que en España. La campaña político-religiosa que adjudica la protección tanto militar como espiritual al santo se inicia desde los comienzos de la Reconquista (finales del siglo viII-principios del Ix), cuando el beato de Liébana, en

57. Joaquín Yarza Luaces, "El santo después de la muerte en la baja Edad Media hispana”, en Manuel Núnez Rodríguez y Ermelindo Silva, La idea y el sentimiento de la muerte en la historia y en el arte de la Edad Media (II), Universidad de Santiago de Compostela, I992, p. Io6. 
2. Andrés Marçal de Saxs, San Jorge matando al dragón, ca. 1420 , retablo, Londres, Victoria \& Albert Museum, núm. I217-I864. Foto: Archivo Fotográfico IIE-UnAM. Reproducción autorizada por el Victoria \& Albert Museum.

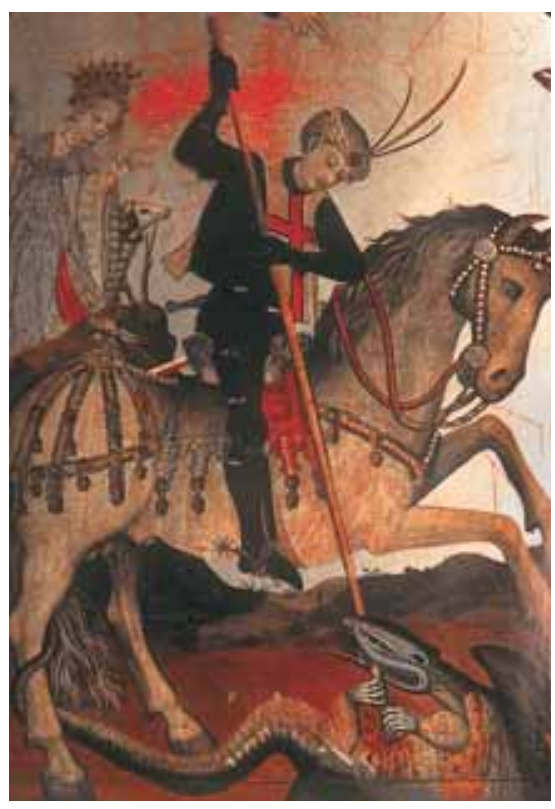

su himno ${ }^{58}$ que empieza con $O$ Dei verbum patris ore proditum, lo introduce en la liturgia del culto a Santiago, lo cual implicaba la vinculación sentimental del santo con la débil monarquía astur-leonesa.

El medio de difusión del culto jacobeo lo constituyeron las peregrinaciones inauguradas en el siglo x por el obispo francés Godescalco de Le Puy. La abadía cluniacense aprovechó el ambiente milenarista para hacer de la peregrinación a Santiago y los distintos caminos jacobeos una red que comunicara y abasteciera el ecumenismo europeo del que se nutría la congregación, a cambio de introducir en territorio hispano un proceso de colonización cultural cristiano-occidental que reintegrara la península como nueva realidad política en el continente e hiciera de Santiago de Compostela su sede metropolitana. 59 Sin embargo, hasta el siglo XI, la figura guerrera de Santiago ecuestre o matamoros, en definitiva, miles Christi, no existe. Las primeras fuentes que apoyan

58. Ángel Sicart Giménez, "La iconografía de Santiago ecuestre en la Edad Media”, Compostellanum, Santiago de Compostela, núm. 27, 1982, pp. I3-I4. No suscribe la general atribución del himno al beato de Liébana.

59. Francisco Márquez Villanueva, Santiago: trayectoria de un mito, Barcelona, Bellaterra, 2004, pp. 35-58, 80-81 y 202-206. 
esta iconografía y comienzan su difusión, aunque no de forma rotunda, pertenecen al siglo XII y serán la base sin excepciones de los posteriores testimonios escritos. En la Historia silense (I II5), se relata la aparición del santo como soldado que anuncia la caída de Coimbra (Io64). Ésta, a su vez, constituirá una de las fuentes del Liber miraculorum del Codex calixtinus (ca. I I40), donde se repite el episodio que ahora tiene carácter milagroso. La actitud pasiva del santo cambia a la acción directa en el Privilegio de los votos o Diploma de Ramiro (ca. II I5), atribuido a Pedro Marcia, canónigo de la catedral de Santiago, desde donde se quieren documentar los legendarios votos realizados por Ramiro I tras la participación activa de Santiago en la batalla de Clavijo (La Rioja, 859). Este dato se recoge en las principales crónicas del siglo XIII, incluida la cancilleresca Primera crónica general (ca. I280), que de este modo consolidan y oficializan definitivamente la leyenda jacobea en Clavijo e incluso la fundación de su propia orden militar, que no ocurrió hasta agosto de i170. ${ }^{60}$ Así pues, el mito de Santiago matamoros se instauraba en Espańa gracias a la prefiguración de un milagro bélico basado, como apuntaba Américo Castro, ${ }^{61}$ en la leyenda de la aparición de los Dióscuros en la batalla del lago Regilo ( $c a .499$ a.C.), favorable a la caballería romana versus la liga latina por la conquista de Roma; ${ }^{62}$ en la iconografía del culto a Cástor como divinidad ecuestre provista de lanza, y en la tradicional creencia, surgida en Oriente, sobre la identidad de Santiago (y otros apóstoles) como "hermano gemelo" del Señor. Esta fragilidad histórica será a la postre, junto con la políticamente incorrecta imagen del santo matamoros, uno de los dos factores que inducirán a que sea, en general, la iconografía menos afortunada del apóstol Santiago, ${ }^{63}$ además de ser la más tardía de todas. Su representación iconográfica más antigua corresponde al siglo XIII y se encuentra en el tímpano de la puerta del brazo meridional del crucero de la catedral de Santiago de Compostela, fechada hacia I220.

En la primera mitad el siglo xiv, la iconografía de Santiago caballero se alterna con la de Santiago matamoros, como podemos observar tanto en el Tumbo B de la biblioteca catedralicia de Santiago de Compostela (I326), el más

6o. Sicart Giménez, op. cit., pp. I5-25.

6I. Américo Castro, España en su historia. Cristianos, moros y judios, Barcelona, Crítica, I984, pp. IO5 y II 2-II3.

62. Pierre Grimal, Diccionario de mitología griega y romana, Barcelona, Paidós, I984, p. 142.

63. Ramón Rodríguez-Bordallo y Ana María Ríos-Graña, "Aportación a la iconografía jacobea", en Giovanna Scalia (coord.), Il pellegrinaggio a Santiago de Compostela, Università degli Studi di Perugia, I985, p. 220. 


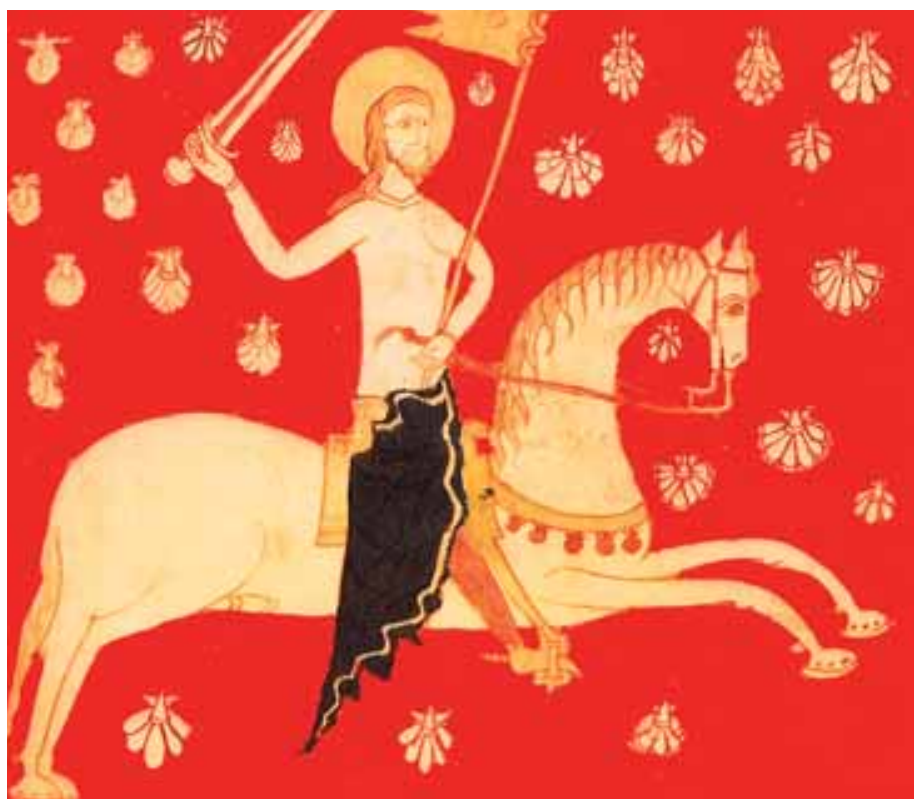

3. Santiago a caballo, tomado de la Guía del peregrino del calixtino de

Salamanca (facsimilar), La Coruña, Fundación Caixa Galicia, I993, s.n.

antiguo con los moros a los pies del caballo, como en el Santiago ecuestre de la Guia del peregrino del calixtino de Salamanca (I330; fig. 3), obras ambas del mismo taller. ${ }^{64} \mathrm{Si}$ bien la naturaleza violenta del santo como "hijo del trueno" no reside sólo en los descabezados sarracenos, ya que en el carisma de su propia milicia y su emblema, la cruz-espada santiagueña, signo semirreligioso y semiguerrero, ${ }^{65}$ se reúnen los nuevos desarrollos iconológicos que vimos antes sobre la cruz y la espada como símbolos militares.

En el segundo cuarto del siglo xv, la imagen de Santiago ecuestre en el tímpano de Betanzos es una réplica del tímpano de Santiago de Compostela. Por tanto, esta imagen se fija como un auténtico ejemplo de "nacionalismo iconográfico" gracias a la política de los Reyes Católicos en la península, y Santiago matamoros será proclamado patrón de España. Por último, en el siglo xvı, la iconografía preferida de los encargos realizados desde el Nuevo Mundo a la

64. Sicart Giménez, op. cit., p. 27.

65. Rodríguez-Bordallo y Ríos-Graña, op. cit., p. 220. 
península ${ }^{66}$ seguirá siendo Santiago, convertido ahora en un mito inquisitorial frente a los nuevos infieles de la Edad Moderna, como Santiago mataindios (fig. 4). ${ }^{67}$

\section{VI}

Y llegamos a la "cima" de esta jerarquía con la figura de san Miguel. Los distintos orígenes del culto a este personaje se relacionan intrínsecamente con las especiales y complicadas cualidades que el arcángel posee. No hubo necesidad de nueva argumentación teológica por cuanto poseía gran tradición bíblica, ya que en el Antiguo Testamento era el príncipe de la sinagoga para los judíos. Su potente identidad — su nombre significa "quien es como Dios" — facilitó la asimilación de toda una serie de cualidades divinas y culturales precristianas que configuran a san Miguel como el arquetipo del mito universal ${ }^{68}$ y que pueden resumirse en tres grupos: el guerrero, el psicopompo y el telúrico.

Por su naturaleza guerrera, al san Miguel caudillo de los ejércitos celestiales princeps militiae angelorum se le relaciona tanto con Wotan, el dios germano de la guerra (por lo que se proclama patrono de los lombardos a principios del siglo viI d.C.), como con Marte, la divinidad latina. Tanto Reau ${ }^{69}$ como Cardini ${ }^{70}$ rechazan este origen germano e indican que el culto primitivo a san Miguel es de origen bizantino, aunque el segundo de ellos destaca la fuerte relación entre los pueblos germanos y la península itálica dominada por Bizancio. El proceso aculturador pudo ser recíproco y no provocar fricciones, por lo que el culto a san Miguel quedó en estas latitudes fuertemente arraigado.

Por su carácter psicopompo (pesador y conductor de las almas) se presenta, aunque con reservas, como una transformación cristiana del culto al mito pagano de Mercurio o Hermes. Su culto se remonta al siglo iv tanto en las comunidades cristianas de Egipto como en Constantinopla, y de allí pasó a

66. María García Páramo, "La iconografía de Santiago en la pintura gótica castellana", Cuadernos de Arte e Iconografía, Madrid, t. vi, núm. II, I993, pp. 92-97.

67. Márquez Villanueva, op. cit., pp. I86-193.

68. Cardini, Alle radici della cavalleria..., op. cit., p. 233.

69. Louis Reau, Iconografía del arte cristiano-Iconografía de la Biblia, Antiguo Testamento, Barcelona, Del Serbal, 1996, t. I, vol. I, p. 67.

70. Cardini, Alle radici della cavalleria..., op. cit., p. 23 I. 
4. Miguel Mauricio, Santiago mataindios, retablo de la iglesia de Santiago de Tlatelolco, México D.F.

Foto: Cecilia Gutiérrez Arriola, 2006. Archivo Fotográfico IIE-UnAm. Reproducción autorizada por el Instituto Nacional de Antropología e Historia. Conaculta-INAH-Méx.

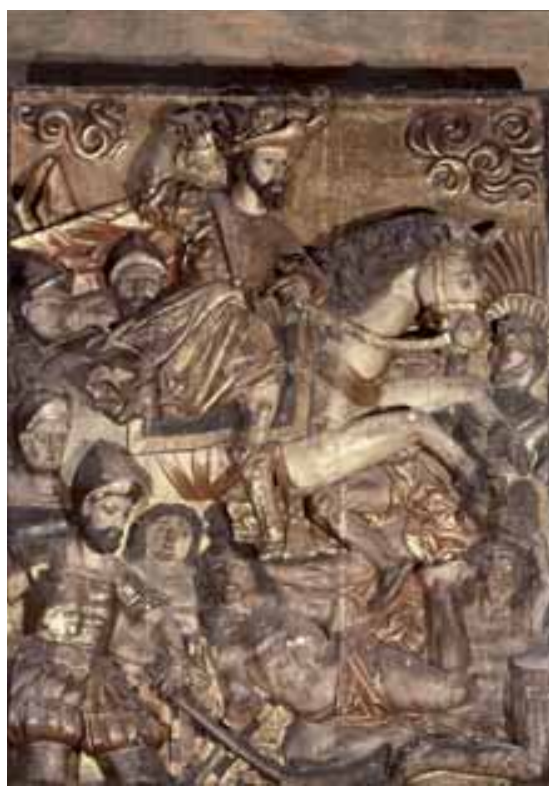

través de Italia a toda Europa. ${ }^{7 \mathrm{I}}$ Hermes nació en una caverna del monte Cileno, al sur de Arcadia, ${ }^{72}$ y, del mismo modo, el culto del arcángel se localiza en una caverna del monte Gárgano. La veneración de san Miguel psicopompo se escenifica, obviamente, en los cementerios, donde predomina su función de pesador de almas: la psicostasia.

También se asocia con otras deidades orientales de ultratumba como Mitra o Anubis, pues no en vano el origen iconográfico de la psicostasia se remonta al Libro de los muertos, por lo que el arcángel también se equipara con el dios Thoth, rey de la Luna y medidor del tiempo caracterizado como un pájaro ibis. Por su índole telúrica, aparece como señor de las fuerzas de la naturaleza, de ahí su éxito y su riquísima simbología. Santiago Sebastián ${ }^{73}$ destaca la ubicación del culto en la montaña como un afán universalmente humano de "conectarse" con Dios, como una llamada a lo alto, a lo trascendente, allí en la cima de lo humano donde la divinidad se encuentra con el hombre. Es,

7I. Santiago Sebastián López, Iconografía medieval, San Sebastián, Donostia, 1988, p. 434.

72. Grimal, op. cit., p. 26I.

73. Santiago Sebastián López, Mensaje simbólico del arte medieval. Arquitectura, liturgia e iconografia, Madrid, Encuentro, I994, pp. 32. 
por tanto, el primero y más sagrado de los santuarios, el arquetipo de todos los templos y por ello, desde la más remota antigüedad, el hombre ha levantado las pirámides, los zigurats y los templos mayas, que obran a manera de montañas artificiales.

Por principio, la montaña sagrada se halla en el centro del mundo y marca un omphalo simbólico de perfección del mundo organizado. El origen del culto telúrico se encuentra en Oriente, concretamente en Frigia, hacia el siglo III d.C. De allí pasó a Bizancio y llegó a Occidente, asentándose a finales del siglo v en el monte Gárgano (Apulia), lugar de su primera aparición (entre 494 y 530). Según La leyenda dorada, ${ }^{74}$ un individuo llamado Garganus observó que uno de sus toros se introdujo en una caverna y, al dispararle una flecha, ésta se volvió contra él. El obispo de Manfredonia, maravillado por el hecho, ordenó tres días de ayuno al final de los cuales san Miguel se apareció en la boca de la caverna y declaró que allí se instauraría su santuario. En el año 708, el arcángel se apareció ante san Auberto, obispo de Arranches, y le ordenó consagrarle una iglesia allí donde se encontrase un toro oculto por ladrones. Este lugar, hoy conocido como mont Saint Michel, se ubicaba en lo alto de un monte llamado Tumba, cercado por el mar. Hubo de hacerse la gruta, pues, a diferencia del monte Gárgano, ésta no existía. En el siglo viI, el papa Bonifacio IV (550-6I5) dedicó a san Miguel una capilla en lo alto del mausoleo de Adriano, también de planta centralizada, circular como la propia planta del mausoleo u octogonal, evidentemente por su carácter doblemente funerario, y de allí le vino el nombre de castillo del Santo Ángel. En este mismo lugar se le apareció a san Gregorio Magno (tercer lugar elevado y circundado) que lo vio secar su espada sangrante y envainarla justo cuando ya finalizaba una epidemia de peste en el año 950, entroncando así con su tradicional veneración en Oriente como médico celestial. Por este carácter telúrico en el medievo, su culto también se celebra in excelsis, bien en santuarios situados en cimas o en capillas ubicadas sobre las puertas de entrada o en las torres de algunos monasterios. Y, tradicionalmente, la imagen de san Miguel era la preferida en las flechas de los campanarios.

La primera psicomaquia aparece descrita en el Libro del Apocalipsis:

Entonces hubo una batalla en el cielo: Miguel y sus ángeles lucharon contra el dragón. El dragón y sus ángeles combatieron, pero no pudieron prevalecer, y no 
hubo puesto para ellos en el cielo. Y fue precipitado el gran dragón, la serpiente antigua, que se llama "Diablo" y "Satanás", el seductor del mundo entero, y sus ángeles fueron precipitados con él. Oí una fuerte voz en el cielo, que decía: "Ahora ha llegado la salvación, el poder, el reino de nuestro Dios. Ellos han venido por la sangre del Cordero y por las palabras de su testimonio, y han despreciado su vida hasta sufrir la muerte..$^{75}$

Curiosamente, salvo las cofradías consagradas al amortajamiento de los difuntos que lo tenían por patrón debido a su carácter psicopompo, el resto de los patronazgos gremiales del arcángel son de origen iconográfico y obedecen a sus dos atributos característicos: la espada para la función psicomáquica y la balanza para la psicostásica. Por su indumentaria caballeresca lo escogieron maestros de armas, esgrimistas, pulidores y doradores. Por la balanza, lo hicieron suyo todos los oficios donde ésta era indispensable o, al menos, muy importante, como pasteleros, boticarios, especieros, pesadores de grano, entre otros. A partir de la Contrarreforma se le consideró el representante de la lucha contra la herejía protestante.

En algunas ocasiones, aparece ejerciendo sus dos funciones principales a un mismo tiempo, conforme a una "doble" iconografía que tiene su antecedente en el san Miguel de Guariento di Pro. ${ }^{76}$

\section{VII}

La Iglesia, para conseguir una integración total de su nueva imagen pública, ahora activista, debió dar todavía un paso más en su estética hagiográfica-caballeresca: introducir en su iconografía al rehabilitado caballero cristiano, ahora compendio de valores morales y virtudes espirituales que tienen en los santos caballeros sus modelos y patronos a seguir. Para conseguir tal objetivo se proyecta esta simbiosis plástica que ha dotado a la iconografía de estos caballeros celestes del mismo tratamiento épico que podría tener cualquier caballero novelesco o histórico y viceversa. En este sentido, veremos a ambos tipos de personajes, en contexto tanto religioso como laico, simbolizar distintas iconografías

75. Apocalipsis, I2, 7-II.

76. Rafael Cómez Ramos, “Sevilla gótica”, en J. Sureda Pons (coord.), La España gótica. Andalucia, Madrid, Encuentro, I992, vol. II, pp. 289 y 327. 
psicomáquicas que, en definitiva, representan la lucha y el triunfo de la Iglesia frente a la herejía y el paganismo. Todo ello se divulgó a través de las rutas de peregrinación gracias al Codex calixtinus, escrito a finales del siglo xII por el arzobispo Turpín, aunque tradicionalmente se atribuye al papa Calixto II ( $c a$. I050-I I24), que instauró el año santo jacobeo. El libro $4^{\circ}$ relata la crónica del ciclo carolino correspondiente a la campaña del emperador en la península ibérica, su derrota en Roncesvalles y la muerte de Roland que, inmediatamente, pasa a formar parte del ciclo iconográfico románico.

Uno de los episodios más escenificados lo constituye la lucha entre Roland y Ferragut, ${ }^{77}$ gigante sirio descendiente de Goliat, narrado en el capítulo xvII. Este pasaje se convirtió en todo un alegato legitimador, tres siglos después de la llamada a la guerra santa a instancia de la Iglesia católica contra el islam. Para ello, nada mejor que simbolizarlo en el personaje histórico y, por tanto, real del emperador Carlomagno, que incorporaba a todos estos valores políticos, militares y religiosos la importante baza de ser un personaje transformado literariamente, merced a las virtudes caballerescas, en una figura épica que, en ocasiones, llegaba a rozar lo fantástico. Primer caballero histórico, y de igual forma héroe cristiano, emparentado con los héroes bíblicos (Sansón, David...) y con Roland, su sobrino, que no duda en sacrificar su vida por defender la ley cristiana y a su Señor natural, se representa la imagen del mártir caballero más cercana en el tiempo que los antiguos soldados romanos santificados. Así, la Iglesia se sirve de los principales personajes y episodios bélico-históricos al incluirlos dentro de su repertorio iconográfico como una alegoría más de las virtudes cristianas.

Franco Cardini ${ }^{7}$ señala cómo en la Chanson de Roland (ca. I I 70) su muerte es presentada como la de un santo caballero, vasallo de un dios guerrero, el Dios de Israel, el Dominus Deus Sabaoth, señor de las batallas y de la venganza. Roland, como guerrero, antes de morir, dirige un canto de amor a su espada Durendal, en cuyo pomo se guardan valiosas reliquias, y luego ofrece en un acto de fidelidad su guante a Dios, quien le envía una legión de ángeles que lo llevan hasta las mismas puertas del Paraíso.

77. Margarita Ruiz Maldonado, El caballero en la escultura románica de Castilla y León, Universidad de Salamanca, 1986, pp. 42-44.

78. Cardini, "El guerrero y el caballero", op. cit., pp. 9I-92. 
Siente Roldán que su tiempo es acabado. Está tendido sobre una empinada colina, vuelto el rostro hacia España. Con una mano golpea su pecho: ¡Dios! — dice— ¡Que tu gracia borre mis culpas, mis pecados grandes y pequeños que cometí desde la hora en que nací hasta el día en que me ves aquí quebrantado! Y tiende hacia Dios su guante derecho. Los ángeles del cielo descienden hasta él.79

Con ello, con independencia de que estilística y formalmente las canciones de gesta reciban influencia de las fórmulas litúrgicas y de los textos hagiográficos o viceversa, destaca, de manera acertada, que lo importante no es tanto que haya habido una cristianización de la cultura caballeresca, como una militarización de algunos modelos de testimonio cristiano considerados aptos para conmover y servir como propaganda del concepto de "perfecto caballero" que abunda en valor y sabiduría en proporción justa. De esta última, el joven Roland adoleció al cometer una imprudencia que le costó la vida.

En definitiva, la pugna spiritualis, tan simbolizada en episodios bélico-históricos colectivos o personales, junto con las figuras de virtuosos caballeros heroicos e históricos como Carlomagno y Roland, representados en cota de malla, y con escudo y espada, que espiritualmente lindan con lo hagiográfico, completa el repertorio iconográfico, en origen de naturaleza laica y guerrera, escogido por la Iglesia como parte del programa ideológico de las Cruzadas emitido, pues, paralelamente a los hechos (primera Cruzada [I096-I099] y caída de Acre [129I]). Se quiere plasmar así la imagen de una nueva Iglesia beligerante que participa con gran capacidad de poder en la política de su tiempo y que defiende activamente sus dominios, gracias ante todo a la institución y a la actividad caballerescas.

Desde el ámbito civil, esta polivalencia iconográfica afectará al caballero en tanto que modifica y amplía su propio estatus social y religioso. Por ello, debe producirse una nueva lectura simbólica de su representación plástica, ahora desde el prisma religioso por el que ha sido asimilado y que del mismo modo él también ostenta como símbolo de rango personal. Es decir, que la psicomaquia o lucha entre el Bien y el Mal puede estar representada por la figura anónima del caballero.

79. Anónimo, El cantar de Roldán, versión de Benjamín Jarnés, Madrid, Alianza, 2003, p. I64, CLXXV. 


\section{VIII}

La representación del caballero contra el dragón será también la imagen tangible de la virtud combativa a través del ejercicio estoico de la lucha (ideología que llegará viva hasta san Ignacio de Loyola). La violencia contenida en la escena se justifica por cuanto transmite la fuerza de la fe. Es un impulso reconducido y puesto al servicio de Dios. El caballero como abogado de la Iglesia cobra una nueva dimensión que se proyecta no sólo desde el ámbito religioso, sino también desde el civil, donde se valora el prestigio social de las motivaciones religiosas que impulsan a la lucha. La imagen del buen caballero cristiano será adoptada por algunos de los grandes caballeros como emblema personal. El mejor ejemplo es el Perceval arrepentido de su alejamiento de Dios y protagonista de la aventura caballeresca religiosa por excelencia, que la búsqueda del Grial avala y legitima.

Sobre su armamento recae también un fuerte contenido simbólico representado iconográficamente como una serie de atributos espirituales que comunican el mundo físico y el espiritual del caballero cristiano. El caballero armado se aísla del mundo. La armadura es una protección física del cuerpo que simboliza la defensa espiritual contra el pecado. La metafórica metalización de su cuerpo absorbe todo el simbolismo propio del metal (esplendor, duración y brillo). Cada pieza del arnés tiene un simbolismo específico. ${ }^{80}$

Ello resulta muy interesante, porque desde los dos ámbitos, el civil y el religioso, se emite un mensaje a la sociedad que por primera vez exaltará los valores individuales frente al grupo. Ya vimos antes cómo la necesidad de legitimar la profesión guerrera condujo a moralizar los actos habituales de la sociedad a través de las Cruzadas. Pero había que justificar también la vida del caballero, vacía de función cuando la guerra cesaba. La caballería como estado vital, como modus vivendi, debía justificarse asimismo. Esta nueva apología de lo individual que representa la vida del caballero errante, desde el punto de vista moral, se realizó a través del concepto de "aventura", perfectamente integrado en el contexto de lo maravilloso y contenido en el repertorio del imaginario medieval, ya que la aventura misma se vivía como un hecho mágico o sobrenatural y también como un modo de formación del caballero. ${ }^{81}$

80. Juan Eduardo Cirlot, Diccionario de simbolos, Barcelona, Labor, I988, p. 82.

8I. Cardini, Quell'antica festa..., op. cit., p. 24. 
La aventura caballeresca es sinónimo de peligro y lo que define a la caballería errante no es exclusivamente la soledad del camino, sino la búsqueda activa del peligro. Mantener una vida peligrosa es lo que define al caballero y ésta es la solución extrema que adopta, por ejemplo, Erec ante las críticas de la corte que lo acusan de haber dejado la caballería por las delicias del amor de su esposa Enid. Esta legitimación moral se articula a través de un nuevo concepto de destino y de heroísmo individual. Los antiguos conceptos de heroísmo y de destino (azar) que exaltaban los cantares de gesta evolucionaron hacia una nueva concepción caballeresca donde el azar se convierte en fortuna individual, ya que la lucha se materializa en un combate donde no sólo interviene la esquiva fortuna. La ayuda y el favor de Dios (juicio de Dios) dispensará la victoria al caballero que posee la razón-verdad, independientemente de sus méritos. Así, lo que acaece sólo puede dividirse entre lo positivo-recompensa y lo negativo-castigo. ${ }^{82}$

La caballería errante, en consecuencia, es un desafío íntimo, un ejercicio ascético, un credo de vida que desarrolla al individuo como ser adulto capaz de encarar su destino y partir en busca de una vida superior. El caballero aparece ante la sociedad como un ser independiente que ha resuelto, como elección personal, alejarse del grupo, marchar extramuros, para enfrentarse a lo desconocido. La fuerte personalidad, el valor y la madurez que se requieren para optar por esta soledad adulta es lo que se valora en el contexto civil. Peligrosa imagen para la Iglesia, que intenta administrarla desde su propia ideología. La imagen del caballero andante que se adentra solitario en el bosque hacia un incierto futuro que le reporte la tan ansiada fama, es decir, el reconocimiento social, simple vanagloria antańo, se convierte ahora en un desierto, una dura travesía ascética en busca de la virtud y en lucha con los propios demonios interiores que lo alejan de su promesa-voto, esto es, la defensa de la cristiandad, de su señor y de los individuos más débiles. Sólo así encontrará el perdurable reconocimiento y la auténtica ascensión: la santidad caballeresca. El desafío al peligro, tan deseado por los jóvenes caballeros para demostrar su bizarría, se convierte en una metáfora del pecado de vanidad que puede arrastrarlos gratuitamente a la muerte y, en todo caso, los aleja del verdadero sentido ascético que comporta la vida errante. Si, como acertadamente señala Le

82. Erich Köhler, La aventura caballeresca: ideal y realidad en la narrativa cortés, Barcelona, Sirmio, 1990, pp. 62-64. 
Goff, ${ }^{83}$ la entrada en el desierto se experimenta según san Jerónimo como un segundo bautismo, entonces el verdadero momento iniciático de un caballero es su primera incursión en el bosque donde debe enfrentarse a su nuevo destino y a sí mismo, habitando un lugar de pruebas y de desarraigo que acabarán por formarlo como persona si lo supera.

El caballero se relaciona, mediante esa inmersión en lo desconocido, en lo fantástico que supone el bosque o el simple camino errático, con una serie de hechos extraordinarios y objetos mágicos que unas veces utiliza en su favor y otras debe enfrentar. Como hemos visto, debido a la fuerza de la nueva cultura laica y a la tolerancia de la Iglesia, lo maravilloso irrumpe en el gótico ${ }^{84} \mathrm{y}$ la cultura caballeresca desempeña en ello un importante papel. Porque, como dice Cardini ${ }^{85}$ "se trata, más que de fantasías, de metáforas". La caballería se erige en instrumento de interpretación de una existencia individualizada que eclosiona en un nuevo canon humano frente al sentimiento medieval del colectivo como unidad orgánica que representa el hallazgo de una Antigüedad redescubierta. ${ }^{86}$

En este contexto programático de la Iglesia, que unifica las virtudes caballerescas y las cristianas y las concentra en la vida errante como medio de penitencia y perdón, podríamos incluir, a modo de ejemplo literario, el Libro del caballero Zifar, pues las similitudes entre la vida del protagonista y la leyenda de san Eustaquio o Plácido han sido subrayadas por muchos críticos. ${ }^{87}$ Como pariente mayor, debe renunciar a su casa y emprender junto con su familia una vida de caballero errante, cuyas hazañas enmienden las faltas que oscurecen su linaje, contando siempre con el arbitrio divino.

En definitiva, la lucha entre el Bien y el Mal en sus diversas acepciones y la revaloración moral de la práctica de la caballería son los dos elementos conceptuales que intervienen en este programa iconográfico, impulsado desde las más altas instancias eclesiales y feudales, corriente figurativa que normalizará y difundirá la nueva línea ideológica emprendida por el cristianismo para conciliar su doctrina con una vida fuertemente militarizada. La caballería aportará el prestigio de una institución civil que aúna y representa ahora

83. Le Goff, Lo maravilloso..., op. cit., pp. 26-29 y 103, y Cardini, "El guerrero y el caballero", op. cit., p. IоI.

84. Le Goff, ibidem, pp. II-I4.

85. Cardini, "El guerrero y el caballero", op. cit., p. Iо2.

86. Köhler, op. cit., p. 48.

87. Joaquín González Muela, Libro del caballero Zifar, Madrid, Castalia, I982, pp. 23-27. 
los más altos valores. Esta simbiosis entre los intereses de los dos principales estamentos, el nobiliario y el eclesial, demuestra la polivalencia de un mensaje "religioso" canalizado a través de la estética caballeresca. Se completa así el proceso evolutivo de la nueva imagen consensuada del poder medieval, que legitima la funcionalidad de cada estamento sin fricciones y justifica su propio estatus privilegiado. Por último, el concepto y representación de guerra santa alivia la moral de ambos, ya que de esta forma se adecuan a sus propias funciones originales el auxilio espiritual y el militar de la sociedad medieval a un mismo tiempo. \$s 